\title{
Concentrations of cadmium, lead, arsenic, and some essential metals in wild boar from Sweden
}

\author{
Anna Malmsten ${ }^{1} \cdot$ Anne-Marie Dalin $^{1} \cdot$ Jean Pettersson $^{2} \cdot$ Sara Persson $^{1,3}$ (D) \\ Received: 14 August 2020 / Revised: 21 December 2020 / Accepted: 25 January 2021 / Published online: 5 February 2021 \\ (C) The Author(s) 2021
}

\begin{abstract}
The wild boar (Sus scrofa) is becoming more common in Europe and has potential to be used as sentinel species for local contamination of heavy metals. Concentrations of nine trace elements (arsenic (As), cadmium (Cd), copper $(\mathrm{Cu})$, iron (Fe), lead $(\mathrm{Pb})$, magnesium $(\mathrm{Mg})$, manganese $(\mathrm{Mn})$, selenium $(\mathrm{Se})$, and zinc $(\mathrm{Zn})$ ) were examined in kidney tissue of 104 female wild boars hunted at three sites in Sweden. The interrelationships between the trace elements and age dependency were investigated. Reproductive health was previously known to differ among animals at the different study sites, but could not be explained by heavy metal concentrations and no associations were found between heavy metals and reproductive parameters. Kidney concentrations of $\mathrm{Cd}$ (mean $4.16 \mathrm{mg} / \mathrm{kg}$ wet weight (w.w.), range 0.16-12.8) were higher than the permissible level for human consumption in $99.9 \%$ of the samples. Pb concentrations were generally intermediate or low (mean $0.14 \mathrm{mg} / \mathrm{kg} \mathrm{w} . \mathrm{w} ., \mathrm{range} 0.03-$ 1.01 ) and exceeded the levels accepted for human consumption in $0.02 \%$ of the samples. Age class was significantly associated with the concentrations of $\mathrm{Cd}, \mathrm{Mg}$, and Mn. Concentrations of As were low (mean $0.02 \mathrm{mg} / \mathrm{kg} \mathrm{w} . \mathrm{w}$., range <0.0001-0.08) and $\mathrm{Cu}$ and Se concentrations were within the ranges of suspected deficiency for $10 \%$ and $4 \%$ of the wild boars, respectively.
\end{abstract}

Keywords $\mathrm{Cd} \cdot \mathrm{Pb} \cdot$ Wild boar $\cdot$ Wildlife toxicology $\cdot$ Heavy metals $\cdot$ Hazard/risk assessment

\section{Introduction}

Nowadays, the environment is polluted by a variety of toxic substances; the wildlife in these environments is also affected. Non-essential and essential metals in an ecosystem are present either because of their natural occurrence in soil or through anthropogenic activities, mainly industry, agriculture, and transportation (Hunter 1976; Hutton 1983). Lead (Pb), cadmium (Cd), and arsenic (As) compounds are among the most toxic contaminants and may affect the health of humans, wildlife, and farmed animals (Järup 2003; Burger 2008; Mandal 2017). These metals have the ability to accumulate in the body, producing chronic effects on the renal, skeletal,

Sara Persson

sara.persson@slu.se

1 Department of Clinical Sciences, Division of Reproduction, Swedish University of Agricultural Sciences, Uppsala, Sweden

2 Department of Chemistry, Analytical Chemistry, Uppsala University, Uppsala, Sweden

3 Department of Environmental Research and Monitoring, Swedish Museum of Natural History, Stockholm, Sweden reproduction, and nervous systems, as well as cancers (Todd et al. 1996; Mohammed Abdul et al. 2015; Nordberg et al. 2018).

Cadmium accumulates predominantly in the kidney, bound to the protein metallothionein. The first sign of toxic effects is tubular dysfunction, caused by the accumulation of $\mathrm{Cd}$ in proximal tubular cells, leading to irreversible damage, followed by proteinuria and later a decreased glomerular filtration rate (Järup 2003). In addition, Cd accumulates in the ovary (Varga et al. 1993) and is suspected to be an endocrine disruptor, mimicking estrogen (Henson and Chedrese 2004) and causing inhibited folliculogenesis (Banu 2013).

Essential metals are normally found in body tissues but may be toxic in high concentrations and cause deficiency symptoms if the concentrations are too low. There are also numerous interactions between the essential and nonessential metals. For example, the concentrations of essential metals such as zinc ( $\mathrm{Zn}$ ) and selenium (Se) can affect the uptake and toxicity of $\mathrm{Cd}, \mathrm{Pb}$, and $\mathrm{As}$ (Brzóska and Moniuszko-Jakoniuk 2001; Hsu and Guo 2002; Kumar et al. 2010; Ognjanović et al. 2008). In addition, having sufficient iron stores is protective for $\mathrm{Cd}$ accumulation (Barregard et al. 2010). Both essential and non-essential heavy metals transfer 
readily in the food chain; the diet seems to be the primary pathway for metal accumulation in both small and large animals (Gall et al. 2015).

The wild boar (Sus scrofa) is an omnivore and, in general, about $90 \%$ of their diet consists of plant matter, but animal matter and fungi are also found (Ballari and Barrios-García 2014; Karlsson 2015). Wild boar diets vary widely between countries being determined by the available food types (Schley and Roper 2003). These opportunistic feeding habits lead to wild boars being good indicators of local environmental pollution and exposure in the terrestrial food chain in diverse geographical areas. Heavy metals may also reach human beings through the food chain, with implications for health (Taggart et al. 2011; Engström et al. 2012) and socioeconomic impacts (Borgström et al. 2006). In Sweden, wild boar meat consumption has become more common as the population of free-ranging wild boar has increased remarkably during the last four decades and about 100,000 animals are hunted per year (Viltdata 2019).

The aim of this study was to investigate the exposure of Swedish wild boars to heavy metals by measuring the kidney concentration of $\mathrm{Cd}, \mathrm{As}, \mathrm{Pb}, \mathrm{Zn}$, copper $(\mathrm{Cu})$, iron $(\mathrm{Fe})$, magnesium $(\mathrm{Mg})$, manganese $(\mathrm{Mn})$, and $\mathrm{Se}$ in females from three study sites. The influence of age and study site on the concentrations was studied, as well as the influence of metals on reproductive status and number of corpus lutea in the ovaries. The suitability of wild boar kidney for human consumption was also investigated.

\section{Materials and methods}

\section{Sample collection}

Between October and December 2015, kidneys from 104 female wild boars were collected during ordinary hunting and frozen at $-20{ }^{\circ} \mathrm{C}$ until analyzed. This collection was done in connection with another project on wild boar reproduction (Malmsten et al. 2017). Sampling was conducted on three estates in different counties in Sweden: estate A, Skåne; estate B, Blekinge; and estate C, Uppland (Table 1). Estate A has an

Table 1 The number of sampled wild boars in total, per sampling region, and per age

\begin{tabular}{llllll}
\hline \multirow{2}{*}{ Sampling site } & No of samples & \multicolumn{2}{l}{ Age class } \\
\cline { 3 - 6 } & & Juveniles & Yearlings & Adult & Unknown \\
\hline A & 25 & 13 & 8 & 4 & 0 \\
B & 40 & 4 & 18 & 12 & 6 \\
C & 39 & 7 & 13 & 18 & 1 \\
Total & 104 & 24 & 39 & 34 & 7 \\
\hline
\end{tabular}

area of $24 \mathrm{~km}^{2}$ under organic farming, with dairy cows and production of cereals, peas, potatoes, sugar beets, oil seed, and animal feed such as hay/ensilage. No large roads are located close to the estate. Estate B is located by a large highway, has an area of $87 \mathrm{~km}^{2}$, and produces corn, cereals, peas, oil seed, and animal feed. Estate $\mathrm{C}$ is also located by a large highway and has an area of $10 \mathrm{~km}^{2}$. It produces mainly cereals and animal feed. Both estates B and C are extensively farmed and both have potential point sources of As from sawmills and nursery gardens and $\mathrm{Pb}$ from shooting ranges.

Commercial hunting of wild boars and other ungulates takes place on all three estates. The estates had similar management strategies for wild boars, which included supplemental feeding throughout the year. The types of feed used were corn, grain, root vegetables, combination of cereal and sugar beets, and silage (anaerobically fermented wheat and oat grains, peas, and clover). The majority of the supplemental feeding was produced locally.

Age was estimated using tooth eruption and tooth replacement according to Matschke (1967), and the animals were divided into juveniles ( $<1$ year), yearlings ( 1 to 2 years), and adults ( $>2$ years) (Table 1$)$. The skulls were not collected for seven of the animals, which prevented age determination. Kidney tissue was stored at $-20^{\circ} \mathrm{C}$ after collection until analysis. The number of animals sampled from each region and in each age class is presented in Table 1.

The reproductive organs were frozen at $-20{ }^{\circ} \mathrm{C}$ until macroscopic laboratory examination. The uteri were cut open and the contents examined. The reproductive stage (juvenile, anoestrus, cyclic, pregnant) was determined based on the macroscopic examination, in accordance to Malmsten et al. (2017). The number of corpora lutea was recorded. Animals in prooestrus, oestrus, metoestrus, and dioestrus were classified as cyclic.

\section{Chemical analyses}

About 0.4 to $0.5 \mathrm{~g}$ of the partly thawed kidney samples was cut using a ceramic knife on a cleaned Teflon surface, accurately weighed and placed in microwave Teflon bombs. After weighing, $6.0 \mathrm{~mL} \mathrm{HNO}_{3}$ (68\% normapure, VWR, France, that is sub-boiled in an all-quartz system) and $0.5 \mathrm{~mL}$ ultrapure $\mathrm{HF}$ (48\% purity, Ultrapure, Merck, Germany) were added to the bombs. The bombs were closed after $15 \mathrm{~min}$ and placed in the microwave digestion system (Titan MPS, PerkinElmer) and the program according to Table S1 in the Supplemental information was followed. The solution (totally clear) was quantitatively transferred to $50-\mathrm{mL}$ Falcon $\mathrm{BD}$ centrifuge tubes together with $1.000 \mathrm{~mL} 50 \mathrm{ng} / \mathrm{mL} \mathrm{Rh}$ before dilution to the 50-mL mark with MQ water. Two blanks were digested in the same manner for every 16 samples that were prepared. The repetition was checked by the preparation of 3 individual samples from one kidney. The limits of quantification (LOQ) 
are reported in Table S2 and information about certified reference materials can be found in Table S3 in the Supplemental information.

\section{Measurements}

Analysis of ${ }^{65} \mathrm{Cu},{ }^{67} \mathrm{Zn},{ }^{57} \mathrm{Fe},{ }^{24} \mathrm{Mg},{ }^{55} \mathrm{Mn},{ }^{111} \mathrm{Cd},{ }^{78} \mathrm{Se},{ }^{75} \mathrm{As}$, and ${ }^{208} \mathrm{~Pb}$ was carried out using a NexION 300D ICP-MS (PerkinElmer, USA) with nickel cones, cyclonic spray chamber, Meinhardt nebulizer (type-C), and standard factory tubing, in a class 1000 clean room environment. The ${ }^{103} \mathrm{Rh}$ was used as internal standard. An energy discriminating quadrupole collision cell with $4.5 \mathrm{~mL} / \mathrm{min} \mathrm{He}$ (99.999\% purity) was used for all isotopes, and no correction equations were used. The instrument was stabilized for at least $45 \mathrm{~min}$ before optimization of the system using the SmartTuneTM function in the control software. This procedure, carried out daily, was used to optimize parameters such as torch position, Ar gas flow for the nebulizer, and the AutoLens settings to maximize signal intensity while minimizing doubly charged ions and oxide species. Single element standards $(1000 \mu \mathrm{g} / \mathrm{mL}$; Teknolab AB, Kungsbacka, Sweden) were measured, with five points, including the zero calibration standard, being used to create the calibration curve. The MS method used three replicate readings of 30 sweeps over the analyte mass range, with an integration time of $75 \mathrm{~ms}$ for each mass per sweep. The sample aspiration rate was $0.3 \mathrm{~mL} / \mathrm{min}$; a sample preflush of $60 \mathrm{~s}$ was done. Elemental concentrations were calculated from the average signals. The instrument was calibrated at the beginning of each run and was checked repeatedly during the measurements. The calibration solutions were prepared in a LAF bench. All concentrations are reported as milligrams per kilogram wet weight.

\section{Statistical analyses}

A generalized linear model (GLM) was used, with sampling site (sites A, B, and C) and age class (adult, yearling, and juvenile) as fixed categorical factors, to calculate the influence of these variables on the concentrations of metals. An interaction term was tested but omitted due to non-significance. The assumptions of linear models were tested using the diagnostic plots generated by the GLM procedure and Cook's $D$ was calculated to assess the influence of individual values. Pairwise comparisons were made by $t$-tests with Bonferroni adjustments and are expressed as least square means (withingroup means adjusted for the other effects in the model) with standard error (SE). Generalized mixed models with location as a random factor were used to calculate the relationship between reproductive status (anestrous, pregnant, cycling) and metal concentrations, with age class included in the $\mathrm{Cd}$ model. A similar model was constructed to analyze the effect of $\mathrm{Pb}$ and $\mathrm{Cd}$ on the number of corpora lutea (age was excluded as a factor due to lack of significance). All models and Pearson correlations were calculated using SAS 9.2 (Milltown, USA); all $p$-values $<0.05$ were considered significant.

\section{Results}

Only 30 samples (29\%) had As concentrations above the limit of quantification (LOQ, Table S2, supplemental information). The concentrations were generally low (mean of the samples $>$ LOQ was $0.03 \mathrm{mg} / \mathrm{kg}$ ) and As was therefore discarded from the GLM model (Table 2). For all other elements, all concentrations were above the limit of quantification.

There was an overall effect of sample region on the concentrations of elements except for $\mathrm{Mg}$ and Se. Pairwise comparisons between the three study sites are shown in Table 3 . The mean kidney concentrations and the calculated percentage of samples above permitted values and below deficiency thresholds are found in Table 4. All samples contained $\mathrm{Cd}$ concentrations above the permitted values. Two samples (2\%) had concentrations above the recommended $\mathrm{Pb}$ concentration threshold. In addition, $\mathrm{Cu}$ and $\mathrm{Se}$ levels were within the range of deficiency for $10 \%$ and $4 \%$ of the wild boars, respectively. These individuals were from all regions and all age classes.

Age significantly influenced the concentrations of $\mathrm{Cd}, \mathrm{Fe}$, $\mathrm{Mg}$, and $\mathrm{Mn}$ (Table 2). However, pairwise comparisons of $\mathrm{Fe}$ concentrations did not reveal a significant difference between the age groups. Adults had significantly higher average concentration of $\mathrm{Cd}(6.14 \pm 0.37(\mathrm{SE}) \mathrm{mg} / \mathrm{kg})$ than both juveniles and yearlings $(2.42 \pm 0.43$ and $3.56 \pm 0.33 \mathrm{mg} / \mathrm{kg}$,

Table 2 Analysis of variance for concentrations of elements in wild boar kidney (full data set is available in the Supplemental information)

\begin{tabular}{llll}
\hline Dependent variable & $R^{2 \mathrm{a}}$ & \multicolumn{2}{l}{ Source of variance (level of significance) } \\
\cline { 3 - 4 } & & Site $^{\mathrm{b}}$ & Age $^{\mathrm{b}}$ \\
\hline $\mathrm{Cd}$ & 55 & $<.0001$ & $<.0001$ \\
$\mathrm{~Pb}$ & 8 & 0.04 & n.s \\
$\mathrm{Zn}$ & 16 & 0.0005 & n.s. \\
$\mathrm{Cu}$ & 32 & $<.0001$ & n.s. \\
$\mathrm{Fe}$ & 31 & $<.0001$ & 0.03 \\
$\mathrm{Mg}$ & 18 & n.s. & 0.001 \\
$\mathrm{Mn}$ & 19 & 0.005 & 0.002 \\
$\mathrm{Se}$ & 1 & n.s. & n.s. \\
\hline
\end{tabular}

${ }^{\text {a }}$ Coefficient of determination for the statistical model (\%), i.e., the proportion of variability that is accounted for by the statistical model

${ }^{\mathrm{b}}$ The effect of site (A-B) and age class (adult, yearling, juvenile), respectively

${ }^{\mathrm{c}}$ Not significant $(p<0.05)$ 
Table 3 Site differences in kidney concentrations ( $\mathrm{mg} / \mathrm{kg}$ wet weight) of metals in wild boar from Sweden

\begin{tabular}{|c|c|c|c|c|c|}
\hline Metal & Site $^{1}$ & LSmean $^{2}$ & $\mathrm{SE}^{3}$ & Min & Max \\
\hline \multirow[t]{3}{*}{$\mathrm{Cd}$} & A & $3.12^{\mathrm{a}}$ & 0.42 & 0.88 & 8.29 \\
\hline & B & $6.11^{\mathrm{b}}$ & 0.37 & 1.94 & 12.8 \\
\hline & $\mathrm{C}$ & $2.89^{\mathrm{a}}$ & 0.33 & 0.16 & 11.6 \\
\hline \multirow[t]{3}{*}{$\mathrm{Pb}$} & $\mathrm{A}$ & $0.09^{\mathrm{a}}$ & 0.03 & 0.03 & 0.27 \\
\hline & B & $0.14^{\mathrm{ab}}$ & 0.02 & 0.04 & 1.01 \\
\hline & $\mathrm{C}$ & $0.18^{\mathrm{b}}$ & 0.02 & 0.03 & 0.84 \\
\hline \multirow[t]{3}{*}{$\mathrm{Zn}$} & A & $21.1^{\mathrm{a}}$ & 1.18 & 15.1 & 27.3 \\
\hline & B & $27.5^{\mathrm{b}}$ & 1.03 & 17.6 & 39.4 \\
\hline & $\mathrm{C}$ & $26.0^{\mathrm{b}}$ & 0.95 & 15.4 & 56.8 \\
\hline \multirow[t]{3}{*}{$\mathrm{Cu}$} & A & $4.98^{\mathrm{a}}$ & 0.46 & 3.19 & 13.9 \\
\hline & B & $8.81^{\mathrm{b}}$ & 0.40 & 3.72 & 15.3 \\
\hline & $\mathrm{C}$ & $6.13^{\mathrm{a}}$ & 0.37 & 2.54 & 11.3 \\
\hline \multirow[t]{3}{*}{$\mathrm{Fe}$} & A & $92.7^{\mathrm{a}}$ & 13.2 & 44.5 & 156 \\
\hline & B & $113^{\mathrm{b}}$ & 11.6 & 58.2 & 243 \\
\hline & $\mathrm{C}$ & $171^{\mathrm{b}}$ & 10.6 & 62.5 & 511 \\
\hline \multirow[t]{3}{*}{$\mathrm{Mg}$} & A & 202 & 5.97 & 171 & 252 \\
\hline & B & 194 & 5.23 & 160 & 222 \\
\hline & $\mathrm{C}$ & 202 & 4.78 & 158 & 446 \\
\hline \multirow[t]{3}{*}{$\mathrm{Mn}$} & $\mathrm{A}$ & $1.58^{\mathrm{a}}$ & 0.07 & 1.28 & 2.24 \\
\hline & B & $1.62^{\mathrm{b}}$ & 0.06 & 0.82 & 1.92 \\
\hline & $\mathrm{C}$ & $1.84^{\mathrm{b}}$ & 0.06 & 1.13 & 3.95 \\
\hline \multirow[t]{3}{*}{$\mathrm{Se}$} & A & 2.34 & 0.14 & 1.65 & 3.16 \\
\hline & B & 2.24 & 0.13 & 0.74 & 3.66 \\
\hline & $\mathrm{C}$ & 2.28 & 0.12 & 0.14 & 6.38 \\
\hline
\end{tabular}

${ }^{1}$ Sites A (Skåne), B (Blekinge), and C (Uppland), see "Materials and methods" for description

${ }^{2}$ Least square means (within-group means adjusted for the other effects in the model, i.e., age). For each element, rows sharing the same letters are not significantly different $(p>0.05)$

${ }^{3}$ Standard error respectively, $p<.0001$ for both comparisons). In contrast, juveniles had significantly higher average concentrations of $\mathrm{Mg}$ $(217 \pm 6.11 \mathrm{mg} / \mathrm{kg})$ than adults and yearlings $(190 \pm 5.22$, $p=.0036$, and $190 \pm 4.69 \mathrm{mg} / \mathrm{kg}, p=.0018$, respectively). The age pattern was similar for Mn concentrations; juveniles had significantly higher average concentrations $(1.89 \pm 0.07$ $\mathrm{mg} / \mathrm{kg})$ than adults and yearlings $(1.55 \pm 0.06, p=.0021$, and $1.61 \pm 0.06 \mathrm{mg} / \mathrm{kg}, p=.0095$, respectively). For age distributions, see Table 1 .

A relatively strong positive correlation was found between $\mathrm{Mn}$ and $\mathrm{Mg}(r=0.70 ; p<.001)$, between $\mathrm{Mn}$ and $\mathrm{Zn}(r=0.68$; $p<.001)$, and also between Se and $\mathrm{Mg}(r=0.62 ; p<.001)$. Moderate correlations were found between $\mathrm{Cu}$ and $\mathrm{Zn}$ $(r=0.52 ; p<.001)$, between $\mathrm{Mg}$ and $\mathrm{Zn}(r=0.53 ; p<.001), \mathrm{Mn}$ and $\mathrm{Fe}(r=0.48 ; p<.001)$, and $\mathrm{Zn}$ and $\mathrm{Fe}(r=0.47 ; p<.001)$. For all other metals, the correlations were relatively weak $(r<0.4)$ or non-existent.

No significant influence of elemental concentrations on reproductive status or on the number of corpora lutea was found.

\section{Discussion}

This is, to our knowledge, the first study to describe the concentration of trace elements in the kidneys of wild boars from Sweden. We found that $\mathrm{Cd}$ was of concern for public health and for the health of the wild boar; in addition, deficiency of $\mathrm{Cu}$ and $\mathrm{Se}$ could be a potential problem. In the present study, the wild boars in all regions received supplementary feed, which was mainly produced locally. Apart from the supplementary feed, the wild boar eats natural vegetation and grub for roots, fungus, worms, etc. (Karlsson 2015; Malmsten 2017). Therefore, we consider the concentrations of metals
Table 4 Mean kidney concentrations ( $\mathrm{mg} / \mathrm{kg}$ wet weight) of metals in Swedish wild boar and comparisons with reference levels

\begin{tabular}{lllll}
\hline & $\begin{array}{l}\text { Arithmetic mean } \pm \text { standard } \\
\text { deviation }\end{array}$ & Range & \% over permitted values ${ }^{\mathrm{a}}$ & $\begin{array}{l}\% \text { deficient } \\
\text { levels }\end{array}$ \\
\hline $\mathrm{Cd}$ & $4.16 \pm 2.88$ & $0.16-12.8$ & $99.9 \%$ & \\
$\mathrm{~Pb}$ & $0.14 \pm 0.14$ & $0.03-1.01$ & $2 \%$ & \\
$\mathrm{As}$ & $0.02 \pm 0.01^{\mathrm{c}}$ & $<\mathrm{LOQ}^{\mathrm{c}}-0.08$ & $0 \%$ \\
$\mathrm{Zn}$ & $25.1 \pm 5.95$ & $15.1-56.8$ & $10 \%$ \\
$\mathrm{Cu}$ & $6.67 \pm 2.60$ & $2.54-15.3$ & \\
$\mathrm{Fe}$ & $129 \pm 74.5$ & $44.5-510$ & $0 \%$ \\
$\mathrm{Mg}$ & $197 \pm 30.5$ & $158-446$ & $0 \%$ \\
$\mathrm{Mn}$ & $1.66 \pm 0.36$ & $0.82-3.95$ & $4 \%$ \\
$\mathrm{Se}$ & $2.30 \pm 0.68$ & $0.14-6.38$ & \\
\hline
\end{tabular}

${ }^{\text {a }}$ Proportion of samples with concentrations over the permitted values for cadmium $(1 \mathrm{mg} / \mathrm{kg})$ and lead $(0.5$ $\mathrm{mg} / \mathrm{kg}$ ) according to European Commission (2006)

${ }^{\mathrm{b}}$ Proportion of samples with concentrations within the deficient range according to Puls (1988)

${ }^{\mathrm{c}} 71 \%$ of the samples were below LOQ (limit of quantification), for which the mean is based on LOQ divided by 2 
to mirror the bioavailability of local metal contamination. If the wild boar is to be used as a tool in environmental monitoring, however, the supplementary feeding could be a potential bias and should be taken into account.

Compared to other wild boar studies from different countries and geographical regions, we found intermediate to low levels of $\mathrm{Pb}$ (see data on $\mathrm{Pb}$ and $\mathrm{Cd}$ compiled in Mulero et al. (2016)). Regarding the highest $\mathrm{Pb}$ concentrations in this study, it cannot be excluded that $\mathrm{Pb}$ from fragmenting bullets might have affected the results. Cadmium was found in moderately high levels, higher than, for example, reports from Spain (Santiago et al. 1998) and Italy (Amici et al. 2012), but similar to reports from Croatia (Bilandžić et al. 2009), and lower than heavily polluted areas in Poland (Durkalec et al. 2015). The $\mathrm{Cd}$ levels were much lower in the wild boars in our study compared to Swedish domestic pigs (mean $0.11 \pm 0.04 \mathrm{mg} / \mathrm{kg}$, Grawé et al. 1997). Arsenic was found in low levels, comparable to the levels found in wild boar hair and hoof in Turkey (Yarsan et al. 2014). A study in Poland found no detectable levels of As at all (Rudy 2010).

We did not find any correlation between the concentration of $\mathrm{Cd}$ or $\mathrm{Pb}$ and any of the other trace elements. This is in contrast to other wild boar studies where correlations between $\mathrm{Cd}$ and $\mathrm{Pb}$ (Medvedev 1999; Gašparík et al. 2017) and between Cd and Mn (Demirbaş and Erduran 2017) were found. Cadmium concentration in kidney is expected to increase with age due to the specific accumulation in this organ. Our study showed that $\mathrm{Cd}$ concentrations were higher in adults compared to younger animals. This is in accordance to other studies (Kuiters 1996; Bilandžić et al. 2010). In addition, we found that $\mathrm{Mg}$ and $\mathrm{Mn}$ were higher in juveniles than in older wild boars; this age effect has not, to our knowledge, been described before. Both $\mathrm{Mg}$ and $\mathrm{Mn}$ are important for skeletal growth (Plumlee et al. 1956; Wallach 1990).

In our study, the levels of $\mathrm{Cd}$ and $\mathrm{Pb}$ differed significantly between sampling locations. Several authors have previously found regional differences of these metals in the tissues of wild boars (Bilandžić et al. 2010; Durkalec et al. 2015; Santiago et al. 1998) that can be explained by point sources such as mining, so it appears that the concentrations in wild boar can reflect local contamination of soil. Our study showed higher levels of $\mathrm{Pb}$ in wild boar from sites that are situated relatively close to major highways (Blekinge (B) and Uppland (C)), compared to the site far away from highways (Skåne (A)), although only significantly so for the site in Uppland. Contamination from leaded gasoline (that was phased out in Sweden during the 1980s) is a plausible reason for this presence. In addition, shotgun pellets could be another potential source, especially as both the B and C sites have shooting ranges within the areas.

The observed higher $\mathrm{Cd}$ concentration in wild boar from the site in Blekinge county (B) compared to the other sites is difficult to explain. The $\mathrm{Cd}$ content in soil is generally higher in Skåne county compared to the other two sites (Eriksson et al. 2010), but local factors such as soil $\mathrm{pH}$ could be relevant for bioavailability. In addition, the $\mathrm{Cd} / \mathrm{Zn}$ ratio in soil could be important (Birke et al. 2017). Historical use of phosphate fertilizers and sewage sludge could possibly play a role (Hutton 1983). Internal factors, such as the levels of $\mathrm{Se}, \mathrm{Fe}$, and $\mathrm{Cu}$, could not explain the differences, as they were intermediate in the wild boars from Blekinge county.

The $\mathrm{Mn}, \mathrm{Mg}$, and $\mathrm{Zn}$ concentrations were within the normal ranges reported for domestic pigs (Puls 1988), and/or similar to studies on domestic pigs (Jorhem et al. 1989; López-Alonso et al. 2007). Reports of Fe concentrations in domestic pigs vary considerably in the literature; the Fe levels in this study were high compared to some studies (Falandysz 1993; López-Alonso et al. 2007; Stasiak et al. 2017), but similar to one study from Poland (Assis and Cruz 2015). The most probable reason for this variation is that there are natural individual differences in Fe storage in the kidney (Morris 1987). High storage levels of $\mathrm{Fe}$ may be related to $\mathrm{Cu}$ deficiency, due to insufficient mobilization of Fe stored in tissues (Lee et al. 1968). We found that the $\mathrm{Cu}$ levels in this study were within the range of deficiency for $10 \%$ of the animals, but $\mathrm{Fe}$ and $\mathrm{Cu}$ were not correlated. Instead, $\mathrm{Cu}$ correlated with $\mathrm{Zn}$, which could be related to co-accumulation from the diet (Zetzsche et al. 2016). Sedki et al. (2003) found that high Cd levels measured in the kidney of sheep and cattle (mean $10.3 \mathrm{mg} / \mathrm{kg}$ ) disrupted normal trace element metabolism by decreasing $\mathrm{Zn}$ and $\mathrm{Cu}$ levels; however, we found no correlation with $\mathrm{Cd}$ in this study. In pigs, $\mathrm{Cu}$ deficiency causes anemia and cardiovascular hypertrophy with risk of rupture of the heart or large arteries (Shields et al. 1962).

For $4 \%$ of the wild boars, the Se levels were so low that Se deficiency could potentially be a problem (Puls 1988). In domestic pigs, Se deficiency results in hepatosis dietetica, nutritional myopathy, and mulberry heart disease (Moir and Masters 1979), and it occurs in geographical areas with naturally low Se levels in soil, Sweden being one of them (Lindberg and Bingefors 1970). Selenium deficiency has been found in the Swedish population of moose (Galgan and Frank 1995).

As $\mathrm{Cd}$ accumulates in the kidneys and the critical effect is renal tubular failure, we compared the concentrations to the lowest observed adverse effect level of $\mathrm{Cd}$ for renal tubular dysfunction in humans. It has been estimated to be $120 \mathrm{mg}$ $\mathrm{Cd} / \mathrm{kg}$ kidney (Nordberg et al. 2018); the level of Cd in the kidneys of wild boar in this study is well below this level, indicating that renal toxicity in wild boar is unlikely. The reproductive toxicity of $\mathrm{Cd}$ has not been as well studied as nephrotoxicity, but examples of the effects on female reproduction include failure to ovulate, defective steroidogenesis, and impaired developmental competence in embryos (see review by Thompson and Bannigan (2008)). In Swedish wild boars from the same regions as in this study, the proportion of 
reproductive abnormalities, such as embryonic/fetal mortality, ovarian cysts, was $10 \%$ in 569 females, and the proportion increased with age (Malmsten et al. 2017). The proportion of abnormalities was significantly higher in females from Uppland compared with Blekinge (Malmsten 2017). The concentrations of heavy metals in wild boar from the same sites did not follow this pattern; therefore, it is improbable that heavy metals have any relation to the reproductive abnormalities reported earlier. In addition, we found no association with reproductive parameters in this study.

The wild boar is a popular game species and is also hunted for consumption. Wild boar meat is considered to be an "organic" alternative to commercially produced pork. In this study, almost $100 \%$ of the samples contained higher Cd levels than the maximum level set for domestic swine kidneys in the EU Commission Regulation No. 1881/2006 of 19 December 2006 (European Commission 2006). Cadmium accumulates mainly in the kidney and liver, with much lower concentrations in muscle (Falandysz 1993; Piskorová et al. 2003; Amici et al. 2012; Crnić et al. 2015). However, there is no correlation between $\mathrm{Cd}$ concentrations in kidney and muscle (Medvedev 1999) and, therefore, predicting the Cd concentrations in muscle is not possible in our study. However, in several studies of wild boar with similar or somewhat higher kidney concentrations as in this study, it was found that if the level of $\mathrm{Cd}$ exceeded the maximum permissible level (set by the EU for domestic pig kidney), there was a proportion of muscle samples also exceeding the maximum permissible concentration in meat (Piskorová et al. 2003; Bilandžić et al. 2009; Bilandžić et al. 2010; Amici et al. 2012; Demirbaş and Erduran 2017; Gašparík et al. 2017). This relationship emphasizes the need for studying the muscle concentrations in wild boar from Sweden, especially as the Swedish government has recently appointed an inquiry on how to facilitate the availability of wild boar meat to the public, as a measure to stimulate culling and limit damage to crops (Swedish Government 2018).

\section{Conclusions}

Cadmium levels in Swedish wild boar kidneys varied in the different study sites and increased with age. However, all $\mathrm{Cd}$ concentrations were sufficiently high to exceed the recommendations for human consumption. Further studies are needed for risk assessment of meat consumption. The concentrations of both non-essential metals and essential metals were not high enough to suspect a negative effect on the general and reproductive health of the wild boars. However, low concentrations of $\mathrm{Cu}$ and $\mathrm{Se}$ were found in some animals, indicating a risk for deficiency.

Supplementary Information The online version contains supplementary material available at https://doi.org/10.1007/s10344-021-01460-y.
Availability of data and material (data transparency) All data can be found in Supplemental information

Funding Open Access funding provided by Swedish University of Agricultural Sciences. This work was funded by the Environmental Monitoring Program at the Swedish University of Agricultural Sciences.

\section{Declarations}

Conflict of interest The authors declare no competing interests

Ethics approval All samples were collected during regular hunting activities and no animals were sacrificed for the sake of this study; therefore, no ethical approval is needed according to Swedish legislation.

Open Access This article is licensed under a Creative Commons Attribution 4.0 International License, which permits use, sharing, adaptation, distribution and reproduction in any medium or format, as long as you give appropriate credit to the original author(s) and the source, provide a link to the Creative Commons licence, and indicate if changes were made. The images or other third party material in this article are included in the article's Creative Commons licence, unless indicated otherwise in a credit line to the material. If material is not included in the article's Creative Commons licence and your intended use is not permitted by statutory regulation or exceeds the permitted use, you will need to obtain permission directly from the copyright holder. To view a copy of this licence, visit http://creativecommons.org/licenses/by/4.0/.

\section{References}

Amici A, Danieli PP, Russo C, Primi R, Ronchi B (2012) Concentrations of some toxic and trace elements in wild boar (Sus scrofa) organs and tissues in different areas of the province of Viterbo, central Iitaly. Ital J Anim Sci 11(4):e65

Assis G, Cruz C (2015) Zinc content in liver and kidney of piglets slaughtered in Portugal. Safepork 2015 Proceedings Book: Epidemiology and control of hazards in pork production chain SAFEPORK, One health approach under a concept of farm to fork. September 2015 Porto - Portugal, pp 263-267

Ballari SA, Barrios-García MN (2014) A review of wild boar (Sus scrofa) diet and factors affecting food selection in native and introduced ranges. Mammal Rev 44(2):124-134

Banu SK (2013) Heavy metals and the ovary. In Hoyer PB. ed, Ovarian Toxicology $2^{\text {nd }}$ ed, CRC Press Taylor and Francis Group Boca Ranton USA, pp 191-228.

Barregard L, Fabricius-Lagging E, Lundh T, Mölne J, Wallin M, Olausson M, Modigh C, Sallsten G (2010) Cadmium, mercury, and lead in kidney cortex of living kidney donors: Impact of different exposure sources. Environ Res 110(1):47-54

Bilandžić N, Sedak M, Dokić M, Šimić B (2010) Wild boar tissue levels of cadmium, lead and mercury in seven regions of continental Croatia. Bull Environ Contam Toxicol 84(6):738-743

Bilandžić N, Sedak M, Vratarić D, Perić T, Šimić B (2009) Lead and cadmium in red deer and wild boar from different hunting grounds in Croatia. Sci Total Environ 407(14):4243-4247

Birke M, Reimann C, Rauch U, Ladenberger A, Demetriades A, JaehneKlingberg $\mathrm{F}$ et al (2017) GEMAS: Cadmium distribution and its sources in agricultural and grazing land soil of Europe - Original data versus clr-transformed data. J Geochem Explor 173:13-30

Borgström F, Zethraeus N, Johnell O, Lidgren L, Ponzer S, Svensson O et al (2006) Costs and quality of life associated with osteoporosis- 
related fractures in Sweden. Osteoporosis International 17(5):637650

Brzóska MM, Moniuszko-Jakoniuk J (2001) Interactions between cadmium and zinc in the organism. Food Chem Toxicol 39(10):967980

Burger J (2008) Assessment and management of risk to wildlife from cadmium. Sci Total Environ 389(1):37-45

Crnić AP, Šuran J, Madunić HC, Božić F (2015) Cadmium concentrations in the tissues of young wild boar (Sus scrofa) from Moslavina and Slavonia in lowland Croatia. Vet Arh 85:323-334

Demirbaș Y, Erduran N (2017) Concentration of selected heavy metals in browne hare (Lepus europaeus) and wild boar (Sus scrofa) from central Turkey. Proceedings in special issue of Balkan Journal of Wildlife Research. 5th International Hunting and Game Management Symposium, November 2016, Debrecen, Hungary 4(2):26-33

Durkalec M, Szkoda J, Kolacz R, Opalinski S, Nawrocka A, Zmudzki J (2015) Bioaccumulation of lead, cadmium and mercury in roe deer and wild boars from areas with different levels of toxic metal pollution. Int J Environ Res 9(1):205-212

Engström A, Michaëlsson K, Vahter M, Julin B, Wolk A, Åkesson A (2012) Associations between dietary cadmium exposure and bone mineral density and risk of osteoporosis and fractures among women. Bone 50(6):1372-1378

Eriksson J, Mattsson L, Söderström M (2010) Tillståndet i svensk åkermark och gröda, data från 2001-2007 (Current status of Swedish arable soils and cereal crops. Data from the period 20012007) Report 6349 Swedish Environmental Protection Agency, Stockholm, Sweden

European Commission (2006) Commission regulation (EC) no 1881/ 2006 of 19 December 2006 setting maximum levels for certain contaminants in foodstuffs. Off J Eur Union:5-24

Falandysz J (1993) Some toxic and essential trace metals in swine from northern Poland. Sci Total Environ 136(1-2):193-204

Galgan V, Frank A (1995) Survey of bioavailable selenium in Sweden with the moose (Alces alces L.) as monitoring animal. Sci Total Environ 172(1):37-45

Gall JE, Boyd RS, Rajakaruna N (2015) Transfer of heavy metals through terrestrial food webs: A review. Environ Monit Assess 187(4):201

Gašparík J, Binkowski ŁJ, Jahnátek A, Šmehýl P, Dobiaš M, Lukáč N, Błaszczyk M, Semla M, Massanyi P (2017) Levels of metals in kidney, liver, and muscle tissue and their influence on the fitness for the consumption of wild boar from western Slovakia. Biol Trace Elem Res 177(2):258-266

Grawé KP, Thierfelder T, Jorhem L, Oskarsson A (1997) Cadmium levels in kidneys from Swedish pigs in relation to environmental factors - temporal and spatial trends. Sci Total Environ 208(1): $111-122$

Henson MC, Chedrese PJ (2004) Endocrine disruption by cadmium, a common environmental toxicant with paradoxical effects on reproduction. Exp Biol Med 229(5):383-392

Hsu P-C, Guo YL (2002) Antioxidant nutrients and lead toxicity. Toxicology 180(1):33-44

Hunter JM (1976) Aerosol and roadside lead as environmental hazard. Econ Geog 52(2):147-160

Hutton M (1983) Sources of cadmium in the environment. Ecotoxicol Environ Saf 7(1):9-24

Järup L (2003) Hazards of heavy metal contamination. Br Med Bull 68(1):167-182

Jorhem L, Sundström B, Åstrand C, Haegglund G (1989) The levels of zinc, copper, manganese, selenium, chromium, nickel, cobalt, and aluminium in the meat, liver and kidney of Swedish pigs and cattle, Gehalt an zink, kupfer, mangan, selen, chrom, nickel, kobalt und aluminium in fleisch, leber und nieren von schwedischen schweinen und rindvieh. Z Lebensm Unters Forsch 188(1):39-44
Karlsson A (2015) Magsäcksinnehåll och reproduktion hos vildsvin i Sverige. (Stomach content and reproduction of wild boar in Sweden) Examensarbete 2014:64 Veterinary programme Second cycle, A2E. Swedish univeristy of Agricultural Sciences, Uppsala, Sweden http://urn.kb.se/resolve?urn=urn:nbn:se:slu:epsilon-s-4170

Kuiters A (1996) Accumulation of cadmium and lead in red deer and wild boar at the Veluwe, the Netherlands. Vet Q 18(sup3):134-135

Kumar A, Malhotra A, Nair P, Garg M, Dhawan DK (2010) Protective role of zinc in ameliorating arsenic-induced oxidative stress and histological changes in rat liver. J Environ Pathol Toxicol Oncol 29(2):91-100

Lee GR, Nacht S, Lukens JN, Cartwright G (1968) Iron metabolism in copper-deficient swine. J Clin Invest 47(9):2058-2069

Lindberg P, Bingefors S (1970) Selenium levels of forages and soils in different regions of Sweden. Acta Agric Scand 20(2):133-136

López-Alonso M, Miranda M, Castillo C, Hernández J, García-Vaquero M, Benedito JL (2007) Toxic and essential metals in liver, kidney and muscle of pigs at slaughter in Galicia, north-west Spain. Food Addit Contam 24(9):943-954

Malmsten A (2017) On the reproduction of female wild boar (Sus scrofa) in Sweden, PhD thesis, Swedish University of Agricultural Sciences, Uppsala Sweden.

Malmsten A, Jansson G, Dalin A-M (2017) Post-mortem examination of the reproductive organs of female wild boars (Sus scrofa) in Sweden. Reprod Domest Anim 52(4):570-578

Mandal P (2017) An insight of environmental contamination of arsenic on animal health. Emerg Contam 3(1):17-22

Matschke GH (1967) Aging european wild hogs by dentition. J Wildl Manage: 109-113

Medvedev N (1999) Levels of heavy metals in Karelian wildlife, 198991. Environ Monit Assess 56(2):177-193

Mohammed Abdul KS, Jayasinghe SS, Chandana EPS, Jayasumana C, De Silva PMCS (2015) Arsenic and human health effects: A review. Environ Toxicol Pharmacol 40(3):828-846

Moir D, Masters H (1979) Hepatosis dietetica, nutritional myopathy, mulberry heart disease and associated hepatic selenium levels in pigs. Aust Vet J 55(8):360-364

Morris (1987) Iron. In Mertz W. ed, Trace elements in human and animal nutrition $5^{\text {th }}$ ed. Academic Press San Diego, California, USA, 79126

Mulero R, Cano-Manuel J, Ráez-Bravo A, Pérez JM, Espinosa J, Soriguer R, Fandos P, Granados JE, Romero D (2016) Lead and cadmium in wild boar (Sus scrofa) in the Sierra Nevada natural space (southern Spain). Environ Sci Pollut Res 23(16):1659816608

Nordberg GF, Bernard A, Diamond GL, Duffus JH, Illing P, Nordberg M, Bergdahl IA, Jin T, Skerfving S (2018) Risk assessment of effects of cadmium on human health (IUPAC technical report). Pure Appl Chem 90(4):755-808

Ognjanović B, Marković S, Pavlović S, Žikić R, Štajn A (2008) Effect of chronic cadmium exposure on antioxidant defense system in some tissues of rats: Protective effect of selenium. Physiol Res 57(3)

Piskorová L, Vasilková Z, Krupicer I (2003) Heavy metal residues in tissues of wild boar (Sus scrofa) and red fox (Vulpes vulpes) in the central Zemplin region of the Slovak republic. Czech J Anim Sci 48(3):134-138

Plumlee M, Thrasher D, Beeson W, Andrews F, Parker H (1956) The effects of a manganese deficiency upon the growth, development, and reproduction of swine. J Anim Sci 15(2):352-367

Puls R (1988) Mineral levels in animal health. Diagnostic data. Sherpa International, Clearbrook, British Columbia, Canada

Rudy M (2010) Chemical composition of wild boar meat and relationship between age and bioaccumulation of heavy metals in muscle and liver tissue. Food Addit Contam 27(4):464-472

Santiago D, Motas-Guzman M, Reja A, Maria-Mojica P, Rodero B, García-Fernández A (1998) Lead and cadmium in red deer and wild 
boar from Sierra Morena mountains (Andalusia, Spain). Bull Environ Contam Toxicol 61(6):730-737

Schley L, Roper TJ (2003) Diet of wild boar (Sus scrofa) in western Europe, with particular reference to consumption of agricultural crops. Mammal Rev 33(1):43-56

Sedki A, Lekouch N, Gamon S, Pineau A (2003) Toxic and essential trace metals in muscle, liver and kidney of bovines from a polluted area of Morocco. Sci Total Environ 317(1-3):201-205

Shields G, Coulson W, Kimball D, Carnes WH, Cartwright G, Wintrobe M (1962) Studies on copper metabolism: Xxxii. Cardiovascular lesions in copper-deficient swine. Am J Clin Pathol 41(5):603

Stasiak K, Roślewska A, Stanek M, Cygan-Szczegielniak D, Janicki B (2017) The content of selected minerals determined in the liver, kidney and meat of pigs. J Elem 22(4)

Swedish Government (2018) Uppdrag att analysera möjligheten att förenkla förfaranden för avsättning av vildsvinskött/Appointment of inquiry for facilitating sale of wild boar meat. N2018/04065/ DL, N2018/01954/DL https:/www.regeringen.se/49fd14/ contentassets/cb1c1c011c91481796eeac5c80fae906/uppdrag-attutreda-forenklade-forfaranden-for-avsattning.docx Accessed 202008-14

Taggart MA, Reglero MM, Camarero PR, Mateo R (2011) Should legislation regarding maximum $\mathrm{Pb}$ and $\mathrm{Cd}$ levels in human food also cover large game meat? Environ Int 37(1):18-25
Thompson J, Bannigan J (2008) Cadmium: Toxic effects on the reproductive system and the embryo. Reprod Toxicol 25(3):304-315

Todd AC, Wetmur JG, Moline JM, Godbold JH, Levin SM, Landrigan PJ (1996) Unraveling the chronic toxicity of lead: An essential priority for environmental health. Environ Health Perspect 104(suppl 1): $141-146$

Varga B, Zsolnai B, Paksy K, Naray M, Ungváry G (1993) Age dependent accumulation of cadmium in the human ovary. Reprod Toxicol 7(3):225-228

Viltdata (2019) Database of hunted game in Sweden. Swedish hunting association. Date accessed: 2019-01-21. https://www.viltdata.se.

Wallach S (1990) Effects of magnesium on skeletal metabolism. Magnes Trace Elem. 9(1):1-14

Yarsan E, Yipel M, Dikmen B, Altıntaş L, Ekici H, Köksal A (2014) Concentrations of essential and non-essential toxic trace elements in wild boar (Sus scrofa l., 1758) tissues from southern Turkey. Bull Environ Contam Toxicol 92(1):10-14

Zetzsche A, Schunter N, Zentek J, Pieper R (2016) Accumulation of copper in the kidney of pigs fed high dietary zinc is due to metallothionein expression with minor effects on genes involved in copper metabolism. J Trace Elem Med Biol 35:1-6

Publisher's note Springer Nature remains neutral with regard to jurisdictional claims in published maps and institutional affiliations. 